\title{
Elachista deriventa sp. n. (Lepidoptera, Elachistidae: Elachistinae), a new species from southern Finland
}

\author{
Lauri Kaila, Marko Mutanen, Esko Saarela, Reijo Siloaho, Leo Sippola \& Jukka Tabell
}

Kaila, L., Mutanen, M., Saarela, E., Siloaho, R., Sippola, L. \& Tabell, J. 2008: Elachista deriventa sp. n. (Lepidoptera, Elachistidae: Elachistinae), a new species from southern Finland. - Entomol. Fennica 19: 184-192.

Elachista (Elachista) deriventa Kaila \& Mutanen sp. n. is described on the basis of specimens collected in southern Finland. The new species inhabits shady forests and Calamagrostis arundinacea is recorded as its host plant. The species is closest to E. elegans Frey, but differs from that by details in morphology and life history. Diagnostic characters and illustrations are provided for close relatives.

L. Kaila, Finnish Museum of Natural History, Zoological Museum, P. O. Box 17, FI-00014 University of Helsinki, Finland; E-mail: lauri.kaila@helsinki.fi

M. Mutanen, Zoological Museum, P. O. Box 3000, FI-90014 University of Oulu, Finland; E-mail: marko.mutanen@oulu.fi

J. Tabell, Laaksotie 28, FI-19600 Hartola, Finland; E-mail: jukka.tabell (a)phet.fi

E. Saarela, Aaltosenkatu 49 E 73, FI-33500 Tampere, Finland

L. Sippola, Ratsutilantie 4 E, FI-33960 Pirkkala, Finland

Received 28 September 2007, accepted 29 October 2007

\section{Introduction}

For a Lepidoptera group, the taxonomy of the microlepidoptera genus Elachista species is, in general, exceptionally premature everywhere in Europe, and recent revisions of species groups or complexes have constantly included descriptions of new species and revealed misconceptions of the identities of type specimens of previously recognised species (cf. e.g. Kaila et al. 2001, Kaila \& Junnilainen 2002, Kaila \& Varalda 2004, Kaila 2005, 2007). Currently, the taxonomic concepts of European Elachista species are in turmoil, and many further changes are to be anticipated.

Thanks to a long entomological tradition and comparatively high number of entomologists, North European microlepidoptera fauna is exceptionally well known. Consequently, discoveries of new species have been infrequent during the last decades. The Elachistinae (Elachistidae) forms there, too, a striking exception. During the last decades, new species have been discovered regularly, among the latest being Elachista tanaella Aarvik \& Berggren, 2003 from northern Norway (Aarvik \& Berggren 2003). No doubt the main reasons for this situation are the cryptic habits of adult moths, combined with morphological similarity among species.

In this paper, we provide description for one recently discovered species. The species was independently discovered twice from separate districts in southern Finland. In autumn 2004, the coauthors ES and LS found some nearly full-fed elachistid larvae on Calamagrostis arundinacea from two nearby localities. Due to the unusual life history, they doubted whether the emerged three adults could belong to E. elegans Frey that the specimens and their life history most resembled. 
Fig. 1. External appearance of Elachista deriventa Kaila \& Mutanen sp. n. Left column $\hat{\jmath}$, from top: Holotype, paratype (ES: Kangasniemi), paratype (EH: Tampere). Right column + , paratypes, all from ES: Kangasniemi.

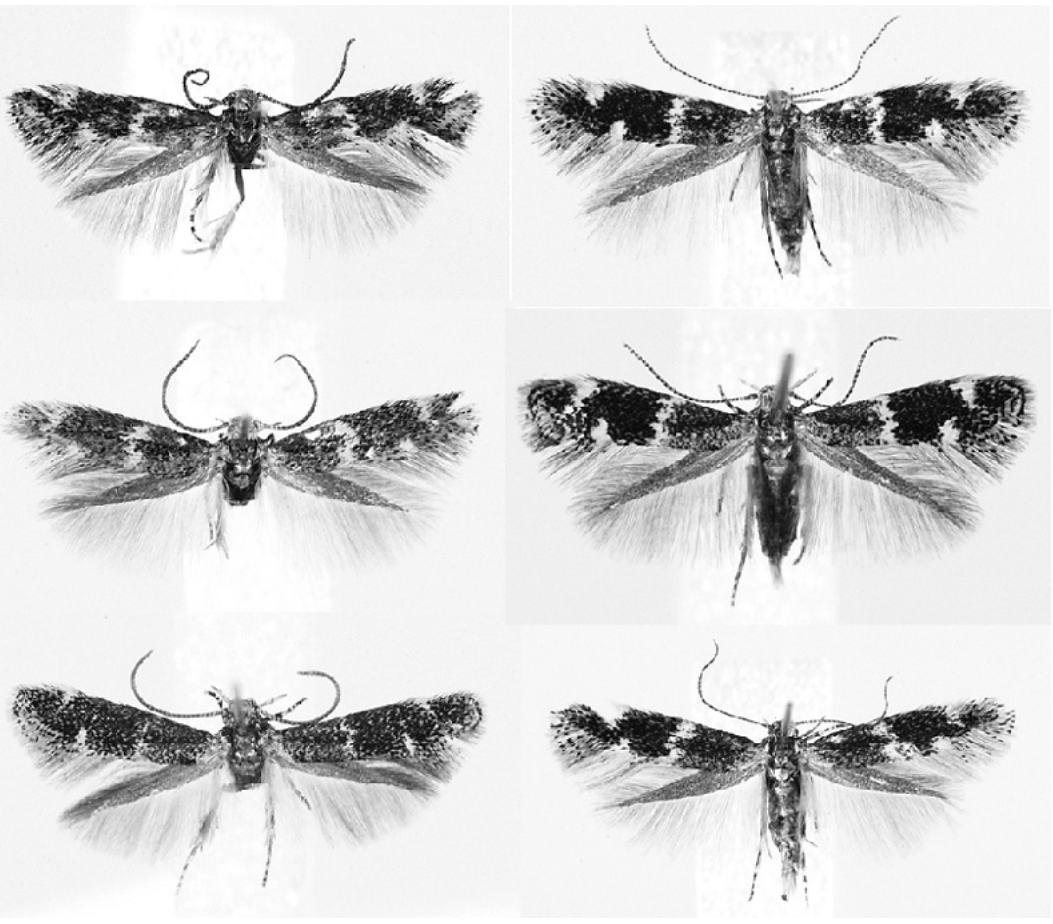

E. elegans indeed feeds on that plant, but does not become full-fed until early summer of next year. The external morphology did not fully match with that species, either. In another district in June 2005, the author MM, collected a male specimen of an odd elachistid, which after examination of its genitalia was found to be different from other known North European species. The author LK confirmed the specimen to belong to an undescribed species. As this specimen appeared conspecific with those reared by LS and ES, and as the food plant and habitat was known, the author RS searched successfully the species from a third district in June 2006.

The author LK has recently examined the type specimens of related species and no revision of this complex of species otherwise seems necessary in foreseeable future. Therefore we deem it better to describe and diagnose the new species separately.

The terminology follows Traugott-Olsen \& Schmidt Nielsen (1977), Kaila (1999a \& b) and Kristensen (2003).

The following abbreviations are used:

- MZH, Zoological Museum, Finnish Museum of Natural History, University of Helsinki, Finland

- ZMO, Zoological Museum, University of Oulu, Finland

\section{Taxonomy}

Elachista deriventa Kaila \& Mutanen sp. n. Figs. 1, 5, 6, 10, 11, 15

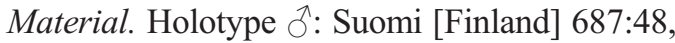
ES: Kangasniemi, 18.VI.2006, R. Siloaho leg., genital slide L. Kaila 4513, coll. MZH. Paratypes (6 ふふર, 17 우, coll MZH, ZMO and private collections of Holmberg, Siloaho, Saarela, Sippola \& Tabell: 2 수, 2 우 same data as in holotype, but 14.VI.2006, genital slides L. Kaila 4514, 4522, 4526, 4527; 2 qo , same data, but 15.VI.2006, genital slide L. Kaila 4645; 3 우, same data, but 16.VI.2006; 1 ㅇ, same data, 3 우, same data, but 20.VI.2006, genital slide L. Kaila 4644; 2 q $ᄋ$, same data, but 21.VI.2006, genital slide L. Kaila 4643; 2 qक , same data, but 26.VI.2006, genital slide L. Kaila 4520; 1 , , Finland, EH: Tampere, 682:33 Aakkulanharju., e. 1. 

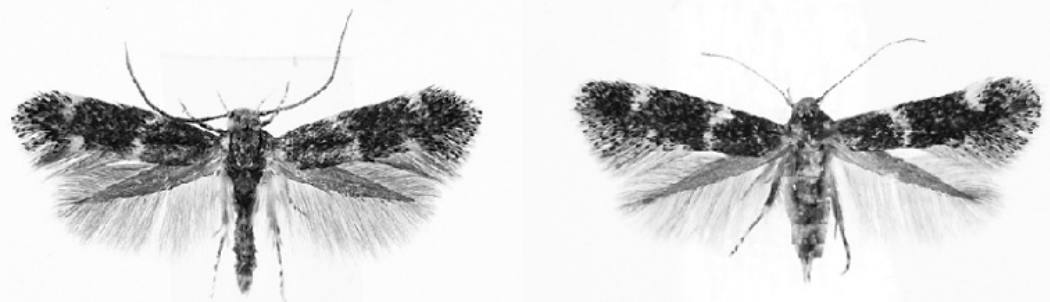

Fig. 2. External appearance of Elachista elegans Frey. Left: $\widehat{\partial}$ (Finland: EH: Hartola ex Calamagrostis arundinacea, emg. 2005, J. Tabell leg. \& Coll.), right $q$ (Finland: EH: Pälkäne, ex Calamagrostis arundinacea, emg. 1992 L. Kaila leg, Coll. MZH)

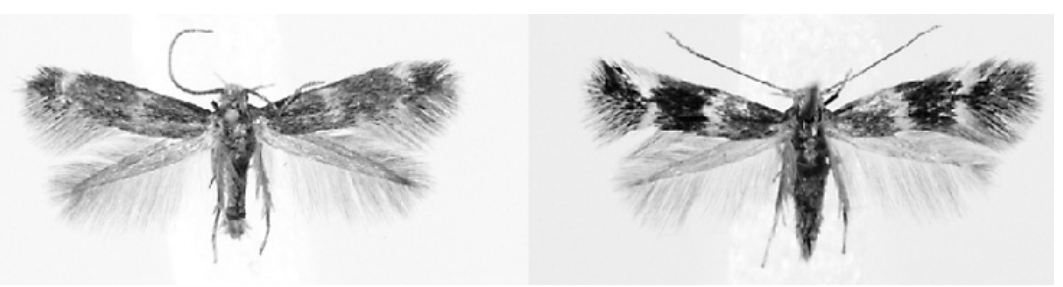

Fig. 3. External appearance of Elachista nielswolffi Svensson. Left: ${ }^{\top}$ (Finland: $K n$ : Puolanka 717:54, 14.VII.2000 R. Siloaho leg.), right + (Finland: PPe: Pudasjärvi 11.12.VII.2000 M. Mutanen leg. \& Coll.).

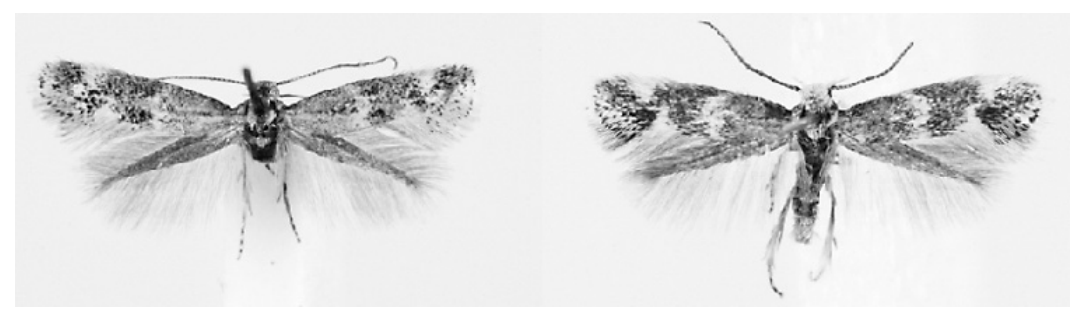

Fig. 4. External appearance of Elachista herrichii Frey $\widehat{\jmath}$. Left: Austria superior, Umgeb. v. Linz, 8.V.1936 J. Klimesch leg., Coll. Hackman, MZH, right: Russia: Ural Cheliabinsk district, Arkaim reserve near Amurskii village 19.V.2004 K. Nupponen leg. \& Coll.

2004 (host: Calamagrostis arundinacea), Esko Saarela leg., genital slide L. Kaila 4464; 1 $\hat{0}$, Finland, EH: Tampere, 682:32 Lielahti, e. 1. 2004 (host: Calamagrostis arundinacea), Esko Saarela leg., genital slide L. Kaila 4460; 1 ふ, EH: Tampere, e 1. 2005, L. Sippola leg., genital slide M. Mutanen 815; 1 ऽ, Finland, EH: Loppi, 67321:3482, 18.VI.2005, M. Mutanen \& P. Välimäki leg, genital slide M. Mutanen 662, DNA sample 04316 Lepid Phyl.; EH: Hartola 6815:444. larva 16.X.2006, emg. 12.2.2007 1 ઈ (host: Calamagrostis arundinacea), J. Tabell leg.; LK: Parikkala 26.VI. 20041 \& H. Holmberg leg. \& Coll., genital slide R. Siloaho 64.
Diagnosis. E. deriventa sp. n. is externally close to several other species of the Elachista bifasciella groups. In particular, it is similar to $E$. elegans Frey, in which the costal and tornal spots are situated more opposite to each other than in $E$. deriventa (Figs. 1, 2). The base of the forewing is unicolorous grey in E. elegans, while there is a whitish spot near base of dorsal margin in $E$. deriventa. The Central European E. albicapilla Höfner is somewhat larger, its costal spot situated at distal 3/4 of the costa, i.e. not as distally as in $E$. deriventa (see Parenti 1987). E. adelpha Kaila \& Jalava, presently only known from the Caucasus Mts, is also similar, but its wing markings are 


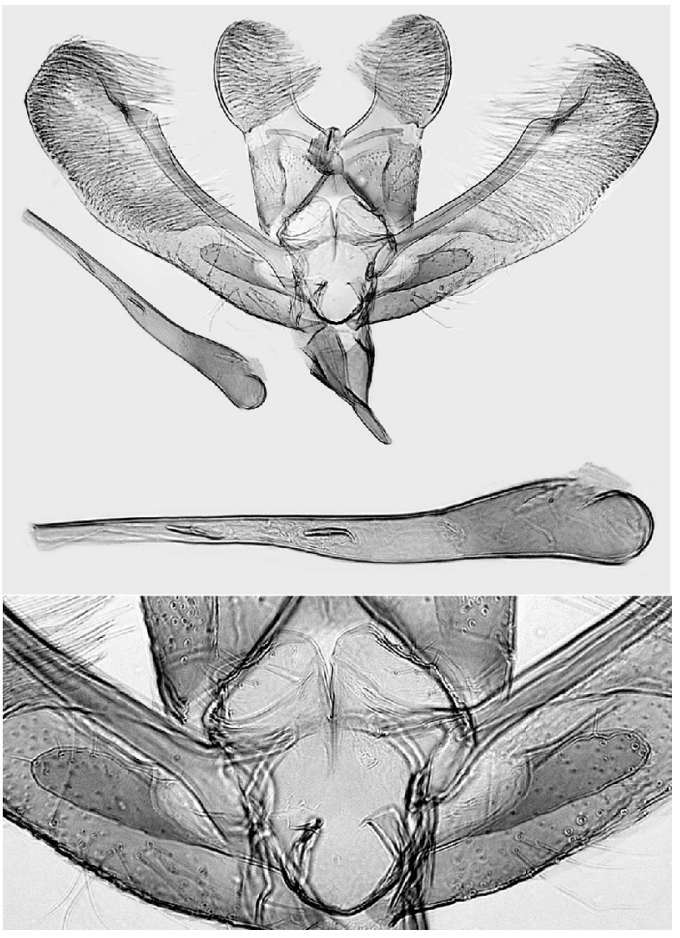

Fig. 5. Male genitalia of Elachista deriventa Kaila \& Mutanen sp. n. Holotype, L. Kaila prep. 4513. Top: general image; middle: phallus enlarged, bottom: juxta and digitate process enlarged.

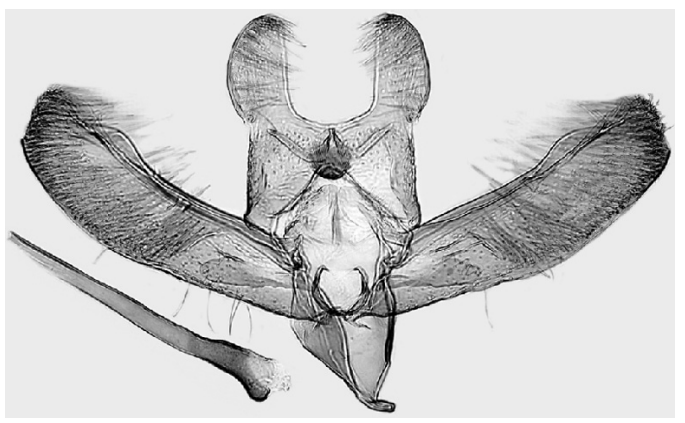

Fig. 7. Male genitalia of Elachista nielswolffi Svensson (L. Kaila prep. 4875, Finland: Kn: Puolanka 717:54, 14.VII.2000 R. Siloaho leg.).

Fig. 9. Male genitalia of Elachista herrichii Frey (L. Kaila prep. 4847, Ukraine: Crimea, Karadagh Nat. Res., Budashkin leg. (MZH).
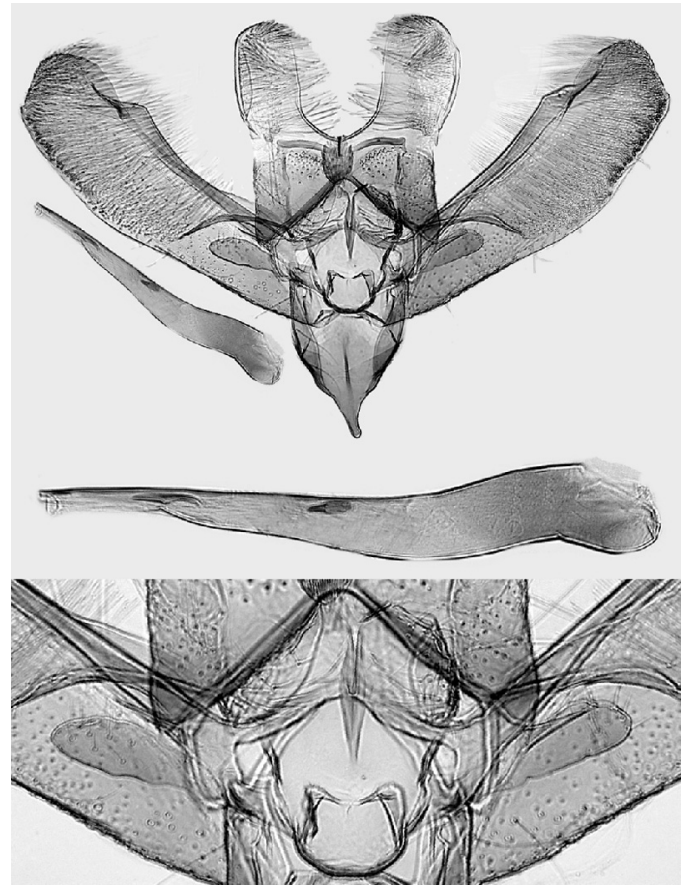

Fig. 6. Male genitalia of Elachista deriventa Kaila \& Mutanen sp. n. Paratype (L. Kaila prep. 4256, ES: Kangasniemi). Top: general image; middle: phallus enlarged, bottom: juxta and digitate process enlarged.

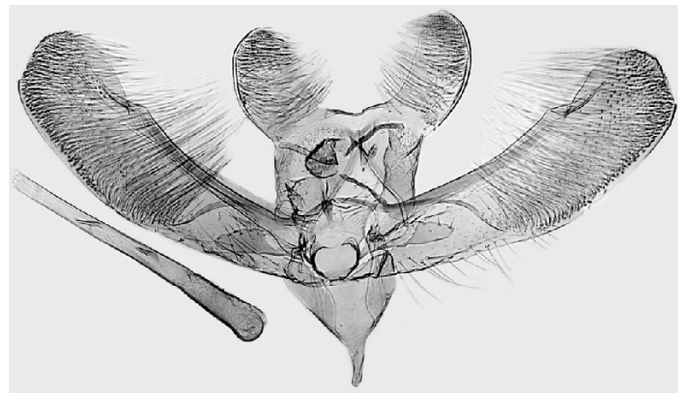

Fig. 8. Male genitalia of Elachista elegans Frey (L. Kaila prep. 4458, Finland: Ps: Kuopio, M. Kononen leg. (MZH).

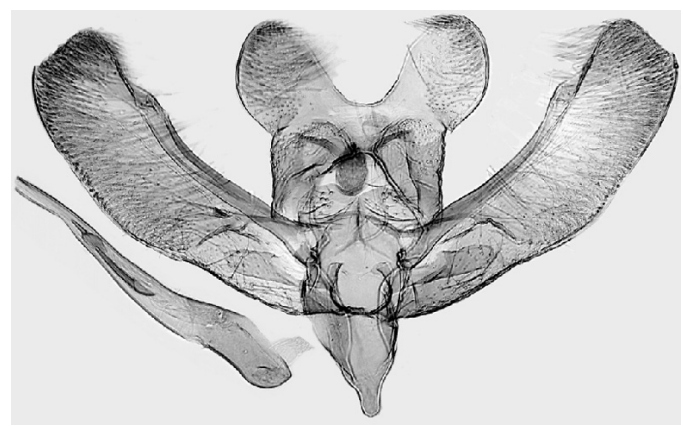




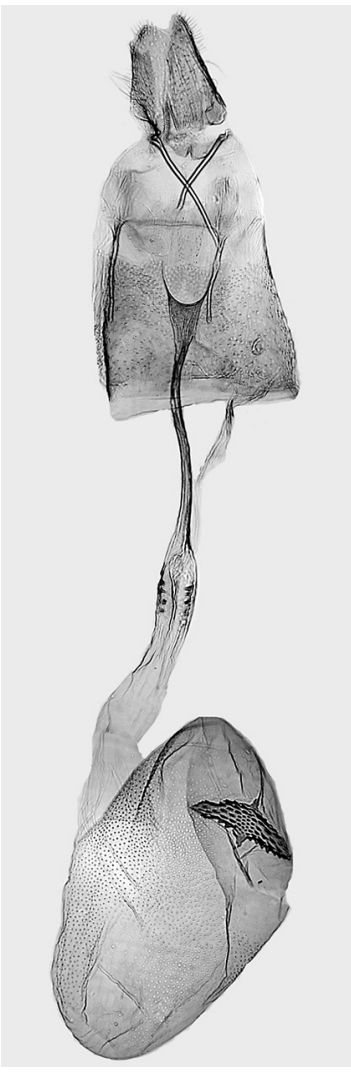

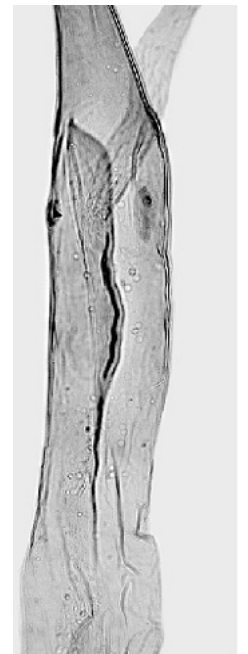
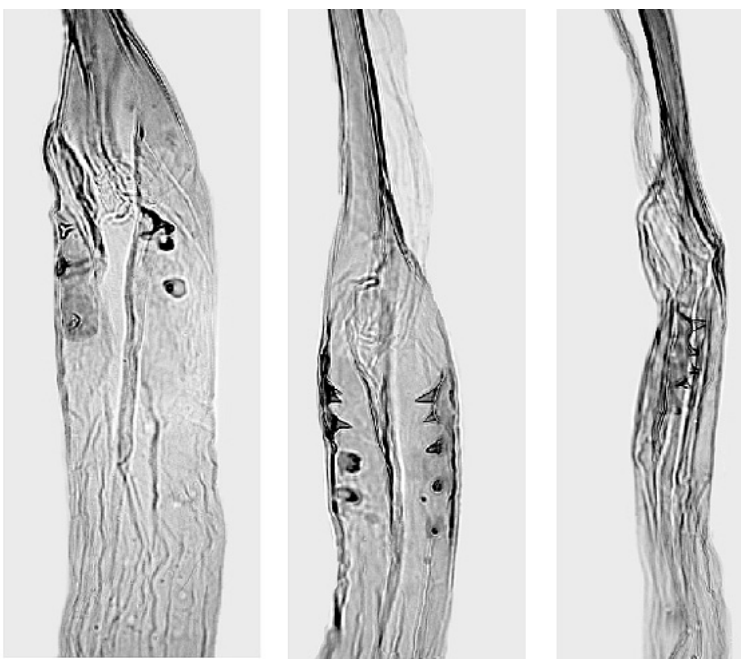

Fig. 11. Variation of the sclerotisation of the female colliculum: all paratypes. From left: Finland: EH: Tampere 682:33, Aakkulanharju e. I. 2004 E. Saarela leg., L. Kaila prep. 4464; Finland ES: Kangasniemi 687:48 26.VI.2006 R. Siloaho leg. L. Kaila prep. 4520, 14.VI.2006 L. Kaila prep. 4522, 21.VI.2006 L. Kaila prep. 4643.

Fig. 10. Female genitalia of Elachista deriventa Kaila \& Mutanen sp. n. Paratype (L. Kaila prep. 4522, ES: Kangasniemi). somewhat more expanded and a little more yellowish (Kaila \& Jalava 1994). The Holarctic, boreomontane E. excelsicola Braun (syn. E. parasella Traugott-Olsen) externally differs as being usually larger, more greyish, frons with grey scales, costal and tornal spots opposite to each other, often confluent with each other giving a symmetric zig-zag-like appearance (see Traugott-Olsen \& Schmidt Nielsen 1977, Kaila 1999b). E. nielswolffi Svensson is blurred bluish grey, costal and tornal spots nearly opposite to each other (Fig. 3). E. zernyi Hartig (syn. E. ingvarella Traugott-Olsen) is usually larger and paler grey, the tornal spot is considerably more proximally placed than the costal spot, usually narrowly confluent giving a zigzag-like appearance (see Traugott-Olsen \& Schmidt Nielsen 1977, Kaila 1999b). Elachista herrichii Frey is significantly paler in appearance (Fig. 4). In the male genitalia (Figs. 5, 6), the species E. adelpha Kaila \& Jalava is otherwise very similar but differs as having no cornuti; E. nielswolffi Svensson has no cornuti, either, and its uncus lobes are much smaller and widely apart from each other (Fig. 7). E. albicapilla Höfner differs as having one cornutus and a very narrow V-shaped incision between the uncus lobes (Parenti 1987). E. excelsicola Braun has more rounded uncus lobes with deep V-shaped incision between them, thinner phallus with much smaller cornuti as compared to E. deriventa (see Traugott-Olsen \& Schmidt Nielsen 1977, Kaila 1999b). The uncus lobes of E. zernyi Hartig are rounded with Ushaped medial incision, phallus not as bulbous proximally as compared to E. deriventa (see Traugott-Olsen \& Schmidt Nielsen 1977, Kaila 1999b). The cornuti of E. zernyi are almost as large as those of E. deriventa. According to the male genitalia, the closest species to $E$. deriventa appear to be E. elegans Frey and E. herrichii Frey. They are identified as follows: the phallus of E. elegans is nearly parallel-sided, i.e. hardly bulbous basally (Fig. 8); this character separates it from both $E$. deriventa and $E$. herrichii. The uncus lobes of $E$. elegans are wider apart from each other, more elongate and curved than in the 


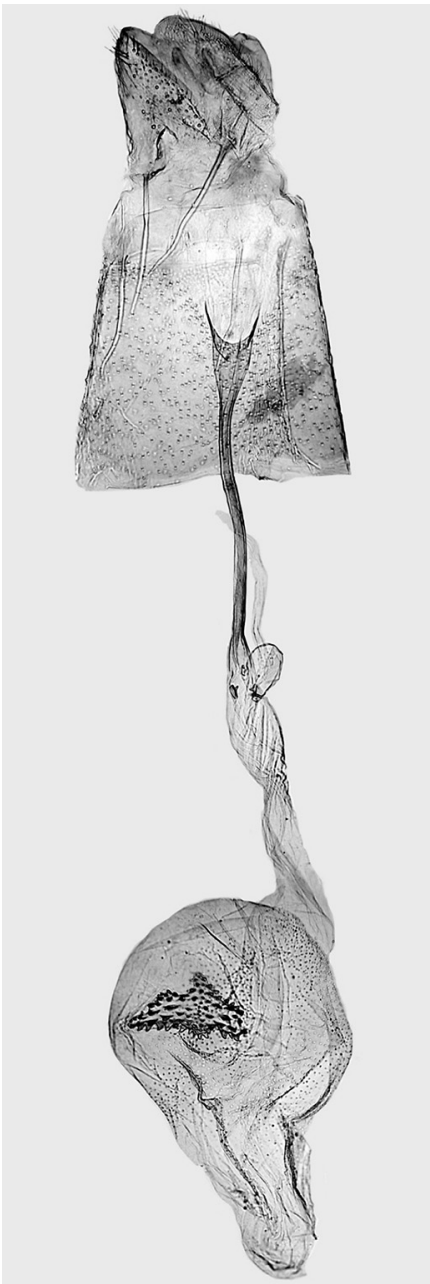

Fig. 12. Female genitalia of Elachista elegans Frey (L. Kaila prep. 4461, Finland: $A b$ : Karjalohja, H. Krogerus leg., $\mathrm{MZH})$.

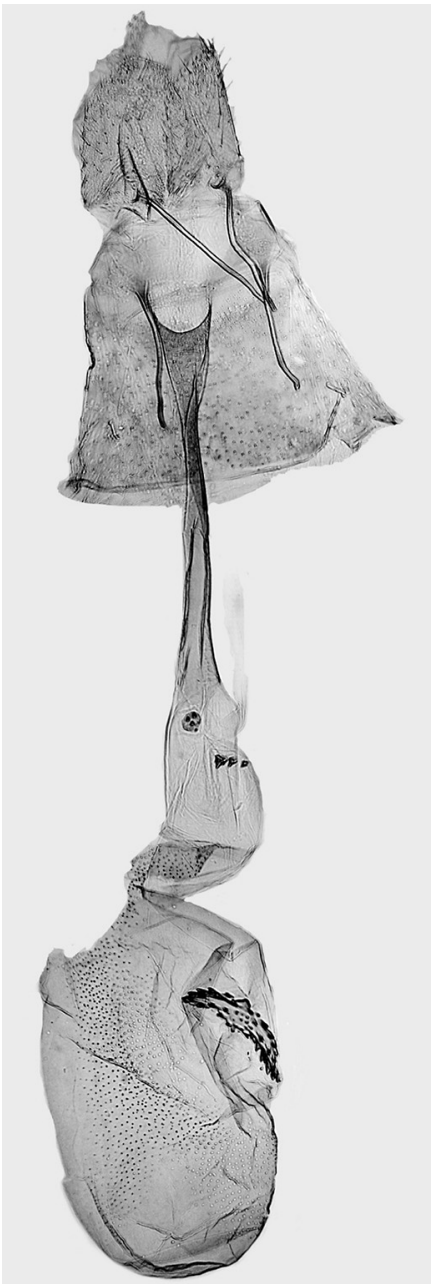

Fig. 13. Female genitalia of Elachista herrichii (L. Kaila prep. 4846, Russia: S. Ural, Orenburg distr. K. Nupponen leg.).

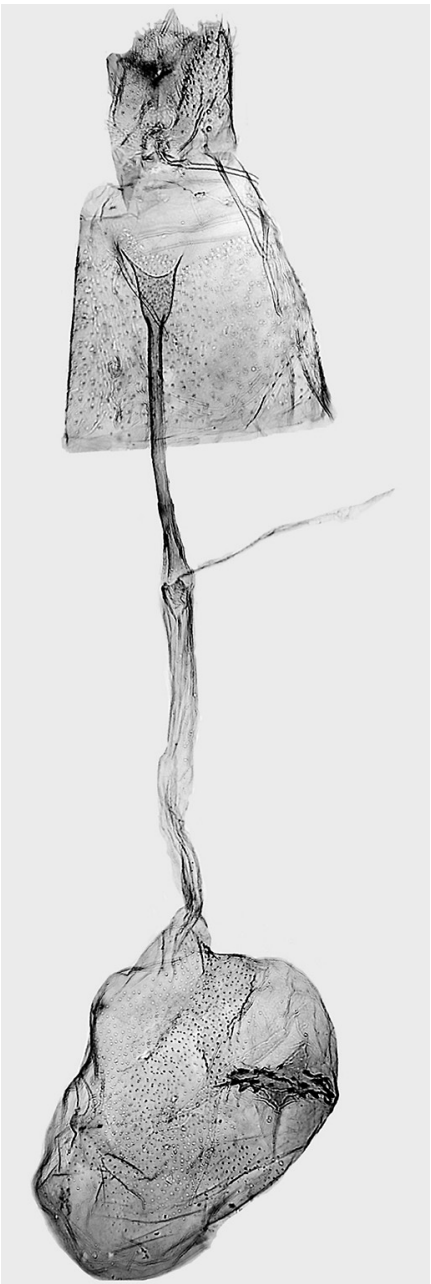

Fig. 14. Female genitalia of Elachista nielswolffi Svensson (L. Kaila prep. 4876, Finland: Kn: Puolanka, R. Siloaho leg., MZH). other two species. E. herrichii is distinctive by its very large cornuti (Fig. 9). The safe identification of $E$. deriventa females by genital characters may require good quality dissection with the genitalia removed from the pelt, and gentle staining with chlorazol black. The female genitalia of E. deriventa are characterised by a paired, yet variable, row of teeth at the ductus bursae cephalad of the inception point of ductus seminalis (Figs. 10, 11). E. herrichii and E. elegans also possess sclerotisations there, but they are more irregular and usually asymmetrical. The base of ductus seminalis is bulbous in E. elegans, tubular in the other spe- cies. The cephalic part of the ductus seminalis is broader in E. herrichii than in the other species (Figs. 12, 13). The female genitalia of $E$. deriventa are closest to those of E. nielswolffi, from which the tooth rows of $E$. deriventa may be the only character of diagnostic value (Fig. 14).

Description. Wingspan. Male 7.3-7.8 mm, female 7.8-9.1 mm.

Male $(n=7)$. Labial palpus ascending, approximately 1.2 times diameter of head, white above, grey below, third segment basally white. Head mottled dark grey above, frons creamy white with almost no darker scaling. Clypeus 
white, mottled with grey. Scape and pedicel of antenna grey, intermixed with creamy white scales, flagellum dark grey, proximally annulated by paler rings, unicolorous dark grey distally. Neck tuft scales pale grey proximally, distally dark grey. Tegula grey with pale grey apex. Thorax dark grey, usually dorsolaterally with whitish scales. Legs greyish, tarsal articles dark grey with conspicuous creamy white rings. Hind tibia creamy white proximally and distally, dark grey medially. Forewing ground colour formed by basally pale and distally broadly dark grey scales giving a mottled dark grey appearance; base of dorsum with rich creamy white scales, forming indistinctly delimited whitish spot; creamy white, narrow, undulating transverse fascia at $2 / 5$ wing length, fascia somewhat variable in width and shape, usually medially more or less outward angled; narrow triangular costal spot of same colour at 4/5 length of costa, and another similar spot at tornus, situated inwards of costal spot. Fringe leaden grey, shorter fringe scales basally whitish, distally almost black forming fringe line. Underside dark grey, base of fringe narrowly yellowish, especially at the place of costal and tornal spots. Hindwing grey above, below dark grey.

Female $(n=17)$. As male, but colour pattern more contrasted: head conspicuously mottled with dark grey especially at vertex; flagellum dark grey, distinctly but variably annulated by white - grey rings; neck tuft scales pale grey basally, distally almost black; tegula dark grey with whitish grey apex giving conspicuously mottled appearance. Thorax blackish grey with scattered scales with white apex. Legs greyish with creamy white patch on femur, tarsal articles dark grey with conspicuous creamy white rings. Hind tibia creamy white proximally and distally, dark grey medially. Abdomen shiny leaden grey dorsally, ventrally segments distally white, giving ringed appearance. Scales of the last segment 9 white. Forewing ground colour almost black, with faint brownish tint, proximal part sparsely scattered with distally white scales, distal part with almost no such scales; costal and dorsal spots rarely medially confluent forming flash-shaped outer fascia.

Male genitalia (Figs. 5, 6). Uncus lobes rather large, slightly longer than wide, median margin almost straight or slightly convex, lateral margins evenly curved; median incision between lobes as wide as or slightly narrower than the lobe itself, more or less wide v-shaped as usually having rather narrow angle mesially. Spinose knob of gnathos almost circular, very small. Valva shape average to E. bifasciella group, nearly straight, distally broadest, basal fold of costa extended to distal 3/4 of valva where meets distal lobe and forming conspicuous hump, sacculus basally straight, medially somewhat truncated, distally straight. Digitate process nearly $1 / 3$ the length of valva, tongue-shaped, with a few setae distally. Juxta lobes slightly produced mesially; mesial margin straight, meeting distal margin without an angle, distal margin weakly convex, setose. Vinculum broad, abruptly tapered into short, slender saccus, median ridge variably distinct (2 out of 6) or absent (4 out of 6). Phallus 3/4 the length of valva, weakly bent as s-shaped, broadest proximally, evenly tapering into a rather pointed distal end, with two equal-sized cornuti formed of narrow-oval shaped basal plate and a curved tooth.

Female genitalia (Fig. 10, 11). Apophyses nearly straight, length variable, apophyses posteriores as long as or somewhat longer than apophyses anteriores. Dense elongated group of minute spines in ventral integument between papillae anales and sternum 8. Ostium bursae deeply incised in sternum 7, broad u-shaped, antrum funnel-shaped. Colliculum entirely occupying caudal part of ductus bursae, slightly longer than sternum 7, more than half of its exceeding beyond the caudal margin of sternum 7; ductus seminalis incepted at middle of ductus bursae, narrow tubular without basal dilation; cephalic part of ductus bursae as long as colliculum, three times wider, tubular and membranous, with 5-10 (exceptionally only 2) sclerotized plates near ductus seminalis, arranged as two longitudinal rows. Corpus bursae oval, largely covered by granules. Signum large, elongated, broadest in the middle, entirely dentate, dentation weakest in the middle.

Life history. The larva is pale yellowish, with weakly sclerotised neck shield. It mines the leaves of Calamagrostis arundinacea (L.) during September and October, becoming full-fed in autumn. The mine, which is situated in the terminal half of the blade and at the leaf margin, is rather 

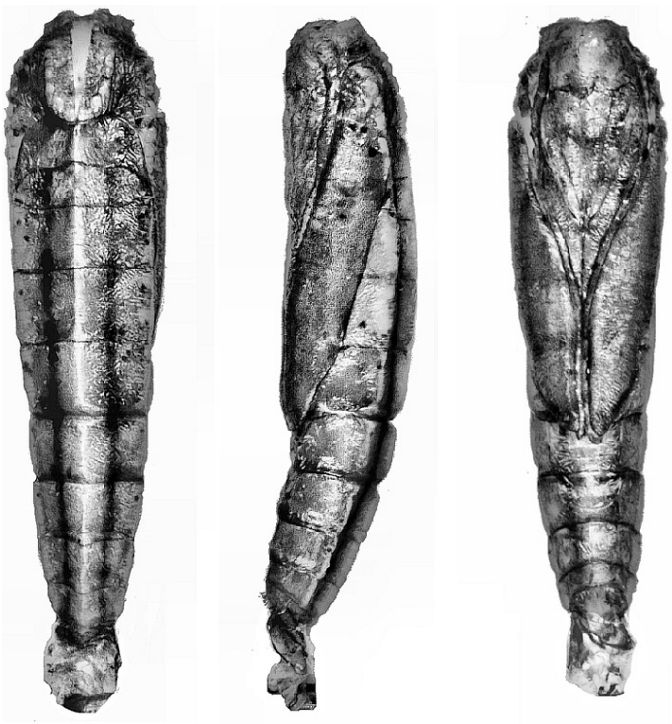

Fig. 15. Pupa of Elachista deriventa Kaila \& Mutanen sp. n., from left: dorsal, lateral and ventral image.

narrow and short, the width being less than half of the blade width and the length about $8-10 \mathrm{~cm}$. The larva mines upwards and packs all frass on either side of the mine. The inhabited mines appear pale yellowish, but are not particularly conspicuous. Pupa (Fig. 15) is alike those of many other species in the E. bifasciella group, with protuberances in thorax, distinctive dorsal and lateral ridges in abdomen, attached on the surface with a silken girdle and with groups of setae on the last abdominal segments ventrally. Adults have been collected relatively early in the summer, between June 14. and June 26. As vast majority of adults collected 2006 in Kangasniemi were females, and as two out of three males were caught in the first day of that period, it is probable that the males should be searched earlier in the summer, presumably in the beginning of June. No specimens have been seen flying actively. All have been either reared from larvae, or collected by sweeping vegetation by the net. Most netted specimens were swept from vegetation early in the morning. Few elachistids are on wing at that time of year in the area, those being exclusively species completing their larval growth in autumn. The four known collecting sites are all forested habitats, varying from rather dry pine forest to more lush mixed and spruce forests, always with rich amount of its host plant.
Distribution. Until now known from four inland districts in provinces $L K, E S$ and $E H$ in southern Finland. It is highly probable that the actual range is wider, particularly towards east.

Diagnosis of larva and mine. At least E. albifrontella $\mathrm{Hb}$., E. apicipunctella Stainton, E. subalbidella Schläger, E. adscitella Stainton and E. elegans are known to feed on the same grass species within the known range of $E$. deriventa. $E$. albifrontella makes during autumn a narrow mine, running $12 \mathrm{~cm}$ first upwards and then turn down and makes equally long mine along midrib. The frass is narrow line running along the middle of the mine. The larva of E. apicipunctella is similar to that of $E$. deriventa but shape of the mine will distinguish these species. E. apicipunctella and E. subalbidella are somewhat polyphagous in various grasses, and like E. deriventa, they complete their life cycle usually already in autumn. Both can reliably be distinguished from $E$. deriventa based on mine and larval morphology: The mine of E. apicipunctella is not situated on the leaf edge and the nearly full-grown larva turns mining downwards. The larva has two sclerotised plates on neck shield which are weaker in $E$. deriventa. The larva of lain E. subalbidella is dark olive green and therefore readily distinguished from both E. deriventa and E. apicipunctella by its colour. The mine is wider than in $E$. deriventa, and the frass is packed in the first half of the mine. E. elegans completes its life cycle in late spring and early summer, being univoltine in southern Finland, but bivoltine in more temperate areas (Traugott-Olsen \& Schmidt Nielsen 1977). Its mine resembles closely that of E. deriventa, but is longer. E. adscitella, which is also polyphagous, completes feeding in the spring. Its mine and larva is as those of E. subalbidella and is therefore easy to distinguish from E. deriventa.

Derivation of name. The name deriventa is a nomen in apposition, somewhat freely composed of the Greek term deris, a contest, and invent (Latin), contrive, implying to the discovery of the species during a inventory race organized by the Lepidopterological Society of Finland.

Acknowledgements. We thank Panu Välimäki for collaboration in the field and Finnish Lepidopterological Society for financial support in clarifying the life history of $E$. deriventa. 


\section{References}

Aarvik, L. \& Berggren, K. 2003: Description of Elachista tanaella sp. n. (Elachistidae) from Arctic Norway. Nota Lepidopterologica 26: 83-87.

Kaila, L. 1999a: Phylogeny and classification of the Elachistidae s.s. (Lepidoptera: Gelechioidea). - Systematic Entomology 24: 139-169.

Kaila, L. 1999b: A revision of the Nearctic species of the genus Elachista s. l. III. The bifasciella, praelineata, saccharella and freyerella groups (Lepidoptera, Elachistidae). - Acta Zoologica Fennica 211: 1-235.

Kaila, L. 2005: A review of Dibrachia Sinev \& Sruoga, 1992, a subgenus of Elachista (Elachistidae: Elachistinae). - Nota Lepidopterologica 28: 139-155.

Kaila, L. 2007: A taxonomic revision of the Elachista bedellella (Sircom) complex (Lepidoptera: Elachistidae: Elachistinae). — Zootaxa 1629: 1-25.

Kaila, L\& Jalava, J. 1994: Elachista adelpha sp. n., E. coeneni titanella ssp. n., and other Elachistidae (Lepidoptera) from North Caucasus. - Entomologica Fennica 5: 97-102.

Kaila, L. \& Junnilainen, J. 2002: Taxonomy and identification of Elachista cingillella (H.-S.) and its close relati- ves (Lepidoptera: Elachistidae), with descriptions of two new species. - Entomologica Fennica 13: 167188.

Kaila, L. \& Varalda, P. G. 2004: The Elachista juliensis complex revisited (Elachistidae). - Nota Lepidopterologica 27: 127-237.

Kaila, L., Bengtsson, B. Å., Šulcs, I. \& Junnilainen, J. 2001: A revision of the Elachista regificella Sircom -complex (Lepidoptera: Elachistidae). — Entomologica Fennica 12: 153-168.

Kristensen, N. P. 2003: Skeleton and muscles: adults. - In: Kristensen, N. P. (ed.), Lepidoptera, Moths and Butterflies Vol. 2: Morphology, Physiology, and Development. Handbuch der Zoologie/Handbook of Zoology IV: Arthropoda: Insecta, Teilband/ Part 36. Walter de Gruyter GmbH. \& Co. Berlin \& New York, pp. 39131.

Parenti, U. 1987: Revisione degli Elachistidi (Lepidoptera, Elachistidae) paleartici, V. Le specie di Elachistidi descritte da Gabriel Höfner. - Bollettino del Museo Regionale di Scienze Naturali - Torino 5: 325-334.

Traugott-Olsen, E. \& Schmidt Nielsen, E. 1977: The Elachistidae (Lepidoptera) of Fennoscandia and Denmark. - Fauna Entomologica Scandinavica 6: 1-299. 